\title{
Quality of life of treated patients with Mirizi syndrome
}

\author{
F. M. Pavuk
}

Uzhhorod National University

\section{Якість життя пацієнтів із синдромом Mirizzi після хірургічного лікування}

\author{
Ф. М. Павук
}

Ужгородський національний університет

\begin{abstract}
Objective. To compare the quality of life of patients with spontaneous internal biliary fistula (SIBF) and without them, before and after surgery.

Materials and methods. 82 (38.7\%) patients were diagnosed with Mirizzi syndrome (MS) type I, and 130 (61.3\%) patients with type II (II-V) type MS. During the study, the classification of A. Csendes - M. Beltran was used. By sex, patients were distributed as follows: there were 68 men (32.0\%), women - 144 (68.0\%). The age of patients ranged from 37 to 80 years (average - 66.4 years). The GSRS (Gastrointestinal Symptom Rating Scale) questionnaire was used to assess quality of life. When comparing groups, the use of Student's t-test comparative mean values and quadratic deviations. The reliability of the obtained $\mathrm{p}$ values were checked by the method of Bonferoni and False Discovery Rate (FDR).

Results. Multiple comparisons with Bonferon and FDR correction revealed statistically significant differences in the results between QOL of patients with MS I and II both before and after surgery. When compared on the scale of total measurement, it was found that the quality of life of patients without SIBF improved by $11 \%$ after cholecystectomy in MS I type. When comparing the results of QOL assessment before and after surgery in patients with type II MS, it was found that QOL after surgery in patients improved by $10 \%$ from baseline.

Conclusions. The quality of life of patients with MS I type is higher compared to patients with SIBF both before and after surgery $(\mathrm{p}=0.0001)$, which is due to impaired bile duct and gastrointestinal tract in SIBF. Elimination of SIBF improves the level of QOL of patients by $10 \%$, which is characterized by a decrease in all items of the GSRS scale.

Keywords: Mirizzi syndrome; quality of life, cholelithiasis.

Реферат

Мета. Порівняння якості життя пацієнтів із спонтанними внутрішніми біліарними норицями і без них до та після хірургічного лікування.

Матеріали і методи. Синдромом Mirizzi I типу діагностовано у 82 (38,7\%) пацієнтів, синдром Mirizzi II (II-V) типу - y 130 (61,3\%) пацієнтів. У дослідженні використана класифікація А. Csendes - M. Beltran. Чоловіків було 68 (32,0\%), жінок - 144 (68,0\%). Вік пацієнтів коливався від 37 до 80 років (у середньому становив 66,4 року). Якість життя оцінювали за опитувальником Gastrointestinal Simptom Rating Scale. При порівнянні показників якості життя застосовували t-критерій Ст'юдента, порівнювались середні значення та квадратичні відхилення. Достовірність отриманих величин р перевіряли, використовуючи поправку Бонфероні та метод False Discovery Rate.

Результати. При проведенні множинного порівняння з поправкою Бонфероні та за методом False Discovery Rate встановлено статистично значущу різницю між якістю життя пацієнтів із синдромом Mirizzi I та II типу як до, так і після операції. При порівнянні за шкалою сумарного вимірювання встановлено, що якість життя пацієнтів без спонтанних внутрішніх біліарних нориць покращилась на 11\% після холецистектомії при синдромі Mirizzi I типу. При порівнянні результатів оцінки якості життя до і після операції у пацієнтів із синдромом Mirizzi II типу встановлено, що якість їх життя після операції покращилась на 10\% від початкового рівня.

Висновки. Якість життя пацієнтів із синдромом Mirizzi I типу вища порівняно із якістю життя пацієнтів із спонтанними внутрішніми біліарними норицями як до, так і після операції ( $\mathrm{p}=0,0001)$, що пояснюється порушенням у останніх жовчовиділення та пасажу жовчі по шлунково-кишковому каналу. Ліквідація спонтанних внутрішніх біліарних нориць покращує якість життя пацієнтів на 10\%, що характеризується зменшенням показників за всіма пунктами опитувальника Gastrointestinal Simptom Rating Scale.
\end{abstract}

Ключові слова: синдром Mirizzi; якість життя; холелітіаз.

Cholelithiasis, or a gallstone disease, is one of the most common and significant illnesses in modern society. The gallstones are most often formed in the gallbladder, so a gallstone disease is complicated by the development of an acute cholecystitis and formation of spontaneous internal biliary fistulas (SIBF) [1 - 4]. Mirizzi syndrome (MS), known as external compression syndrome, is a rare complication of cholecystitis and chronic cholelithiasis, secondary to obstruction of the gallbladder isthmus, caused by exposure to one or more stones in these anatomical structures, resulting in the partial or complete compression obstruction of the common hepatic duct with subsequently impaired liver function. The blockade of a bile passage by mechanical barrier, not only causes a spectrum of functional chang- 
es in a number of organs and systems, but can lead to the SIBF formation as well [5]. The presence of SIBF is accompanied not only by impaired bile flow, but also in some patients by violation of its passage through the gastrointestinal tract (GIT), reflux cholangitis, intestinal obstruction and obstructive jaundice.

Cholangitis in MS occurs due to the open path for penetration of the gastrointestinal tract flora into the bile duct. This creates the conditions for the development of ascending infection, which causes inflammatory changes in both the biliary tract and liver parenchyma. Due to the loss of its reservoir function, the gallbladder in MS turns into a "tube" that takes away bile, or a "blind bag" with bile residues and a thick precipitate, which turns it into a favorable environment for the development of microorganisms that come in contact through hemato- or lymphogenic way. In addition, this is facilitated by anatomical and physiological features of the gallbladder wall structure, prone for folding and active absorbing $[6,7]$. Given the fact that the course of MS in most patients is asymptomatic, there is a tendency while accidental finding of SIBF to become a mostly "unpleasant", disrupting a conventional course of elective surgery [8].

If cholecystectomy is sufficient for the MS Type I, then the amount of surgical treatment for SIBF depends on the fistula level. Of course, the difference in the treatment methods can affect their results and quality of life (QOL) of the patients [9-11].

The aim of the study: to compare the QOL of patients with and without SIBF before and after surgery.

\section{Materials and methods}

Analysis of the examination results in 8100 patients with a gallstone disease, treated in the Transcarpathian Regional Clinical Hospital named after Andriy Novak in 1997 - 2020 yrs, of whom in 212 (2.5\%) the MS was diagnosed, including the disease Type I - in 82 (38.7\%), and Type II (II-V) - in 130 (61.3\%). The study used the classification of A. Csendes - M. Beltran.

There were 144 (68.0\%) women and 68 (32.0\%) men. The patients' age have ranged 37-80 yrs old, averaging $66.4 \mathrm{yrs}$.

QOL was assessed, using the GSRS (Gastrointestinal Symptom Rating Scale) questionnaire, developed by the QOL Study Division at ASTRA Hassle (I. Wiklund, 1998) and applied for the QOL estimation in patients with gastrointestinal disease [6]. The translated version of the GSRS questionnaire was considered a reliable, valid and sensitive. The questionnaire have consisted of 15 items, which were grouped into 6 scales: abdominal pain (AP), reflux syndrome (RS), diarrhea syndrome (DS), dyspepsia syndrome (DS), constipation syndrome (CS), and a total measurement scale. The indicators were estimated by a score of 1 to 7, with higher values, corresponding to greater severity of symptoms and lower QOL.

For statistical analysis we have applied a software package Microsoft Exel 2019 and Jamovi 1.6.14. Student's T-test was used to compare QOL values, namely - the mean values and square deviations. The validity of the $\mathrm{P}$ values obtained was checked using the Bonferoni correction and the False Discovery Rate (FDR) method.

\section{Results}

All 82 patients with the MS Type I have underwent cholecystectomy with suturing of the wide and short vesical ducts. The patients with the MS Type II (II-V) were distributed, depending on the fistula type, and appropriate oneor multi-stage surgery performed (Table 1).

Choledocho-duodenal fistulas, found in 22 patients according to fibroduodenoscopy, we divided into two types depending on the location. In 19 patients the fistula was located in the border of the transitional fold of the large duo-

Table 1. Surgical interventions, depending on the type of MS

\begin{tabular}{|c|c|c|}
\hline MS type & Type of operation & $\begin{array}{l}\text { Number } \\
\text { of patients }\end{array}$ \\
\hline \multirow{2}{*}{ I } & Cholecystectomy "from the bottom" + suturing of wide and short vesical ducts & 56 \\
\hline & Cholecystectomy "from the neck" & 26 \\
\hline \multicolumn{3}{|l|}{ II (II-V), fistulas } \\
\hline \multirow{3}{*}{ cholecystocholedocheal } & Cholecystectomy + reconstruction of CBD remnants of the gallbladder wall & 14 \\
\hline & Cholecystectomy + hepaticojejunoanastomosis & 9 \\
\hline & Cholecystectomy + reconstruction of CBD on frame drainages & 30 \\
\hline \multirow{3}{*}{ Cholecystoduodenal } & Cholecystectomy + pyloroplasty according to Judd & 12 \\
\hline & Cholecystectomy + suturing of the duodenal wall & 4 \\
\hline & Cholecystectomy + gastrectomy by Billroth-II & 6 \\
\hline \multirow{2}{*}{ Cholecystogastric } & Cholecystectomy + pyloroplasty according to Judd & 12 \\
\hline & Cholecystectomy + suturing of the stomach wall & 3 \\
\hline Cholecystocolonic & Cholecystectomy with suturing of the wall of the colon & 12 \\
\hline \multirow[t]{2}{*}{ Combined } & $\begin{array}{l}\text { Cholecystectomy + reconstruction of CBD remnants of the gallbladder wall + suturing } \\
\text { of a wall of a colon }\end{array}$ & 3 \\
\hline & Cholecystectomy + suturing of the duodenal wall + suturing of the wall of the colon & 3 \\
\hline \multicolumn{2}{|l|}{ Total ... } & 190 \\
\hline
\end{tabular}


Table 2. QOL indicators of patients with MS

\begin{tabular}{|c|c|c|c|c|c|c|c|c|}
\hline \multirow{3}{*}{ Scale } & \multicolumn{4}{|c|}{ Type of MS } & \multirow{3}{*}{$\mathrm{p}$} & \multirow{3}{*}{$\mathrm{p}_{1}$} & \multirow{3}{*}{$\mathrm{p}_{2}$} & \multirow{3}{*}{$\mathrm{p}_{3}$} \\
\hline & \multicolumn{2}{|c|}{$\mathrm{I}(\mathrm{n}=35)$} & \multicolumn{2}{|c|}{ II $(\mathrm{II}-\mathrm{V})(\mathrm{n}=40)$} & & & & \\
\hline & $\begin{array}{l}\text { before } \\
\text { surgery }\end{array}$ & $\begin{array}{l}\text { after } \\
\text { surgery }\end{array}$ & $\begin{array}{l}\text { before } \\
\text { surgery }\end{array}$ & $\begin{array}{l}\text { after } \\
\text { surgery }\end{array}$ & & & & \\
\hline AP & $5,23 \pm 0,18$ & $4,89 \pm 0,12$ & $5,73 \pm 0,23$ & $5,28 \pm 0,17$ & 0,0001 & 0,0001 & 0,0001 & 0,0001 \\
\hline RS & $3,56 \pm 0,15$ & $3,23 \pm 0,11$ & $4,18 \pm 0,22$ & $4,02 \pm 0,16$ & 0,0001 & 0,0004 & 0,0001 & 0,0001 \\
\hline DS & $3,28 \pm 0,34$ & $3,12 \pm 0,15$ & $4,59 \pm 0,21$ & $3,78 \pm 0,20$ & 0,01 & 0,0001 & 0,0001 & 0,0001 \\
\hline IS & $6,15 \pm 0,21$ & $5,88 \pm 0,18$ & $5,86 \pm 0,19$ & $5,23 \pm 0,21$ & 0,0001 & 0,0001 & 0,0001 & 0,0001 \\
\hline $\mathrm{CS}$ & $4,63 \pm 0,17$ & $3,12 \pm 0,10$ & $4,88 \pm 0,13$ & $4,56 \pm 0,12$ & 0,0001 & 0,0001 & 0,0001 & 0,0001 \\
\hline $\begin{array}{c}\text { Scale total } \\
\text { measurement }\end{array}$ & $4,57 \pm 0,21$ & $4,04 \pm 0,13$ & $5,04 \pm 0,17$ & $4,57 \pm 0,18$ & 0,0001 & 0,0001 & 0,0001 & 0,0001 \\
\hline $\begin{array}{l}\mathrm{p}-\text { con } \\
\text { (II-V) } \\
\text { type be }\end{array}$ & $\begin{array}{l}\text { ore and a } \\
\text { gery; } \mathrm{p} 3\end{array}$ & $\begin{array}{l}\text { gery; } \mathrm{p} 2 \\
\text { arison o }\end{array}$ & $\begin{array}{l}\text { rison } \\
\text { tients }\end{array}$ & $\begin{array}{l}\text { tients } \\
\text { type a }\end{array}$ & typ & 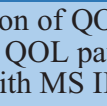 & V) $t$ & $\begin{array}{l}\text { MS II } \\
\text { (II-V) } \\
\text { surgery. }\end{array}$ \\
\hline
\end{tabular}

denal papilla (first type), and in 3 patients - above the transitional fold (second type).

In 19 patients endoscopic papillo-fistulotomy was performed in order to drain the common bile duct (CBD), evacuate the stones from it and eliminate the fistula. At the location of the fistula above the transition fold in 3 patients a singly papillo-sphincterotomy was performed to eliminate the blind pocket of the terminal CBD from the fistula to the large duodenal papilla ampoule.

QOL was assessed before and after surgery in 35 patients with the MS Type I and 40 patients - with the MS Type II (II-V).

It was found, that the number of early postoperative complications in patients with MS of both Types was almost the same. In the early postoperative period, the wound infection was observed in 10 (5\%), and an acute pancreatitis in 4 (2\%) patients. Five (2.5\%) patients with the MS Type II died, and some of these patients underwent single- and multi-stage surgeries.

Clinically, the MS Type I was manifested either by acute cholecystitis with symptoms of obstructive jaundice, but without the stones in hepatico-choledochus, or it was latent cholangitis with asymptomatic course in some patients. Instead, the patients with SIBF were observed to have obstructive jaundice, manifesting reflux cholangitis, aerobilia, abdominal pain, signs of intestinal obstruction, dyspepsia, and diarrhea.

For a more complete picture of the QOL associated with changes in the abdominal cavity after surgery for MS, we compared the corresponding indicators assessed by the GSRS questionnaire (Table 2).

A multiple comparison with the Bonferoni correction and the FDR method have shown a statistically significant difference between the QOL in the patients with the MS of Type I and Type II (II-V) both before and after surgery. Therefore, according to the obtained data, it is safe to assume that the QOL of patients with the MS Type II (II-V) before surgery is worse than the QOL in patients with the MS Type I by $10 \%$. This can be explained by functional disorders that occur due to the presence of SIBF, what in turn worsens the course of cholecystectomy.
When compared on a scale of total measurements, it was found that the QOL of patients without SIBF was improved by $11 \%$ after cholecystectomy in the MS Type I. When comparing the results of the QOL assessment before and after surgery in patients with the MS Type II (II-V), it was found that QOL after surgery have improved by $10 \%$ from a baseline. This can be explained by the elimination of SIBF, cholangitis and restoration of the passage via GIT $(p=0.0001)$.

\section{Discussion}

MS occurs, according to various authors, in $0.5-0.7 \%$ of patients operated on for diseases of the biliary tract, and is one of the complications of a gallstone disease, what increases the risk of the gastrointestinal tract injury, and constitutes a kind of a "trap" for the surgeons [4].

With formation of MS there are new functional relationships, which greatly impact the function of both - the biliary system and GIT, as they on a "parity" basis are involved in the fistula formation. New functional changes include: reflux of intestinal contents into the bile duct, the possibility of ascending infection, functional disorders of the bile secretion. In addition to pathological changes in the "bile tree", similar changes can occur in those parts of the intestinal tube with which the connection was formed [5].

The course of MS may be asymptomatic for a long time, but sometimes over time the severe complications may develop, which directly threaten the patient's life. "Asymptomatic" MS is conditional, because it is a complication of a gallstone disease, which has its own clinical manifestations. It is more correct to talk about "nonspecificity" of the MS symptoms on the background of clinical manifestations of a gallstone disease.

A number of authors describe an interesting phenomenon of disappearance or "smoothing" in clinical symptoms of a gallstone disease in patients with SIBF, possibly due to migration of gallstones from the lumen of the bladder and its scarring "shrinkage" due to chronic inflammation [8 10]. Other authors, on the contrary, note the increase in attacks of biliary colic, strengthening of the inflammation signs. This "reverse" phenomenon is explained by gradu- 
al accession to exacerbations of cholangitis in the chronic calculous cholecystitis manifestations. The presence of SIBF can lead not only to entry of intestinal contents into the bile pathways, but also to the migration of gallstones into the lumen of the intestinal tube, which in the case of a prolonged stay, become the nucleus of giant bezoars, causing an acute intestinal obstruction. Patients with intestinal obstruction of a gallstone genesis (biliary ileus) constitute $3.7 \%$ of those with intestinal obstruction and $1.4-1.5 \%$ - of the operated for a gallstone disease [11, 12].

Nowadays a number of unresolved issues remain in the diagnosis and surgical treatment of MS as one of the complications of a gallstone disease. Despite the wide choice of surgical techniques for this syndrome, the results of treatment need to be improved. Accidental intraoperative presence of MS increases the risk of intra- and postoperative complications and, as a consequence, reduces QOL of the patients. Difficulties in preoperative diagnosis of MS, the risk of the biliary tract damage, as well as a wide range of methods of surgical treatment make the study of this problem relevant.

One of the tasks in the SIBF surgical treatment is to restore the flow of bile into the GIT lumen. In the treatment of MS, along with open surgical methods, effective and secure new endoscopic procedures are applied. Endoscopic preoperative procedures may be used as a method of reduction or elimination of certain life-threatening symptoms, before radical surgery or as a procedure, leading to elimination of some types of choledocho-duodenal fistulas. Application of modern minimally invasive techniques in the treatment of MS is directed on improvement of the patient's QOL before radical surgery and reduction of the accompanying symptoms, caused by impaired bile passage through the gastrointestinal tract.

\section{Conclusions}

1. The QOL in the MS Type I patients is higher compared to the QOL of patients with SIBF, both before and after surgery $(p=0.0001)$, what is associated with a failure of a bile passage through the gastrointestinal tract.

2. Elimination of SIBF improves the level of QOL in the patients by $10 \%$, what is characterized by a decrease in all scales of the GSRS questionnaire.

Funding. No source of funding has been received for this work.

Competing interests. The authors have no conflict of interest.

\section{References}

1. Syplyviy V, Ievtushenko D, Petrenko G, Ievtushenko A. Surgical management of patients with Mirizzi syndrome. HPB. 2016;18(Suppl 2):e674-e5. doi: 10.1016/j.hpb.2016.01.033.

2. Dutka Y, Chooklin S. The special features of surgical treatment of patients with the Mirizzi syndrome. HPB. 2016;18:e820. doi: https:// doi.org/10.1016/j.hpb.2016.01.389.

3. Zaporozhchenko B, Bondarets D, Borodaev I, Kachanov V, Muravyov $\mathrm{P}$, Zubkov $\mathrm{O}$, et al. Modern diagnostic methods and approaches to the surgical treatment of Mirizzi syndrome. Ukrainian Journal of Surgery. 2018;(4):33-7. Rbssian. doi: 10.22141/19972938.4.35.2017.118890.

4. Booij KAC, de Reuver PR, van Dieren S, van Delden OM, Rauws EA, Busch OR, et al. Long-term Impact of Bile Duct Injury on Morbidity, Mortality, Quality of Life, and Work Related Limitations. Ann Surg. 2018 Jul;268(1):143-50. doi: 10.1097/ SLA.0000000000002258. PMID: 28426479.

5. Flores-Rangel GA, Chapa-Azuela O, Rosales AJ, Roca-Vasquez C, Böhm-González ST. Quality of Life in Patients with Background of Iatrogenic Bile Duct Injury. World J Surg. 2018 Sep;42(9):2987-91. doi: 10.1007/s00268-018-4564-3. PMID: 29520485.

6. Turan N, Aşt TA, Kaya N. Reliability and Validity of the Turkish Version of the Gastrointestinal Symptom Rating Scale. Gastroenterol Nurs. 2017 Jan/Feb;40(1):47-55. doi: 10.1097/ SGA.0000000000000177. PMID: 28134719.

7. DeykaloIM, OsadchukDV, KarelOI, MaknitskyiAV, Nazarko LR. Bouveret's syndrome. Klin Khir. 2017 Dec 20;(12):78-9. Ukrainian.

8. Qurbonov N, Salim SD, Rakhmanov KE, Zayniyev AF. Current Trends in the Management of Mirizzi Syndrome: A Review of Literature. Annals of the Romanian Society for Cell Biology. 2021 Apr 10;25(4):1927-32.

9. Chon HK, Park C, Kim TH. Minimally Invasive Approach Using Digital Single-Operator Peroral Cholangioscopy-Guided Electrohydraulic Lithotripsy and Endoscopic Nasogallbladder Drainage for the Management of HighGrade Mirizzi Syndrome. Clin Endosc. 2021 Feb 18. doi: 10.5946/ce.2021.015. Epub ahead of print. PMID: 33596635.

10. Tyvonchuk OS, Tereshkevich IS, Babii IV. Laparoscopic removal of concrement in Bouveret syndrome. Klin khir. 2020 Jun 26;87(34):102-4. Ukrainian. doi: 10.26779/2522-1396.2020.3-4.102

11. Sato H, Hiraki M, Miyoshi A, Ikeda S, Koga H, Kitahara K. The strategy for Mirizzi syndrome type II with laparoscopic surgery: A case report. Int J Surg Case Rep. 2020;77:673-676. doi: 10.1016/j. ijscr.2020.11.106. Epub 2020 Nov 21. PMID: 33395871; PMCID: PMC7710499.

12. Roschyn GG, Tutchenko MI, Iskra NI, Rudyk DV. Some diagnostic and therapeutic aspects of Bouveret syndrome. Health of Society. 2017;(3):47-50 doi: 10.22141/2306-2436.6.3.2017.123491.

Received: 13.12 .2020 